\title{
TEACHING LEGAL ETHICS: EXPLORING THE CONTINUUM
}

\author{
Edmund B. Spaeth, JR.," Janet G. Perry,"* and Peggy B. Wachs ${ }^{* * *}$
}

\section{INTRODUCTION}

The only reason to teach legal ethics, or professional responsibility, is to try to make the legal profession more worthy of its stated ideals. ${ }^{1}$ In our title, we call the University of Pennsylvania Law School Center on Professionalism's efforts to do this "Exploring the Continuum." We say "exploring" because we have found that teaching legal ethics is an exploration. The enterprise demands intellectual rigor, it requires probing the core values of the legal profession, and it leads continually to new and expanding ideas. Thus, the premises on the basis of which we select and present our teaching materials have steadily evolved in ways that have surprised us since this Center began some eight years ago, and we expect they will continue to evolve. "Continuum" is short-hand for the principal conclusion we have reached: Nothing, or at least very little, will be done to make the profession more worthy until legal ethics is taught as a continuum. This education should start in the first year of law school and continue throughout law school and beyond, to include practicing lawyers and judges.

In what follows, we explain how we came to this conclusion by describing our courses and how we develop them. We pay particular attention to two projects made possible by the support of the W.M. Keck Foundation: a group of specialized units, or "modules," on professional responsibility designed for inclusion in other law school courses such as Family Law, Civil Procedure, and Corporations; and a judicial ethics course, which will use literature and film to define themes around which such traditional materials as judicial canons, statutes, and cases will be organized.

Let us say up front that our work is driven by both optimism and despair. As we survey the legal profession today, we see a scene that would have

\section{Copyright $@ 1996$ by Law and Contemporary Problems}

* Director Emeritus, Center on Professionalism, University of Pennsylvania Law School; Of Counsel, Pepper, Hamilton \& Scheetz; former President Judge, Superior Court of Pennsylvania; Director, Judicial Ethics Project.

** Program Director, Center on Professionalism and Director, Professional Responsibility Modules Project, University of Pennsylvania Law School.

*** Associate Director, Center on Professionalism, University of Pennsylvania Law School.

1. MODEL CODE OF PROFESSIONAL RESPONSIBILITY preamble (1980) ("The continued existence of a free and democratic society depends upon recognition of the concept that justice is based upon the rule of law grounded in respect for the dignity of the individual and his capacity through reason for enlightened self-government. . . . Lawyers, as guardians of the law, play a vital role in the preservation of society."); see also MODEL RULES OF PROFESSIONAL CONDUCT preamble (1995). 
delighted Jonathan Swift. While the leaders of the profession proclaim its fundamental virtue, ${ }^{2}$ and while teaching and writing about legal ethics flourish, reprehensible behavior even among the most acclaimed lawyers persists. ${ }^{3}$ It is our earnest conviction that this situation will not change unless the law schools accept some responsibility for teaching the profession's ideals not only to law students but to practicing lawyers and judges. By itself, ethics education will not be enough. But we think it is an essential part of what must be done. In this article, we try to describe the shape we think the educational efforts should take.

II

\section{The Basic LaW School Course on Professional Responsibility}

In order to consider any reformation of the basic law school course on professional responsibility, we must understand from whence we have come. Historically, these courses have been regarded with disinterest. We show how law schools have attempted to do better and explain how to design an improved professional responsibility course.

\section{A. The Bad Old Days}

As in many law schools, at the University of Pennsylvania Law School, professional responsibility used to be taught as an upperlevel course in a traditional way. That is, it was taught from a casebook, by an occasional visiting lawyer whose experience would give immediacy to some issue, such as zealous representation of an unpopular client. The course was, if not a disaster, close to it. Most students took the course only because it was required for graduation. They put it off until the last semester; they did not care about their grade, for they were assured of graduation and most of them had jobs lined up; and they did as little work as possible.

There were two reasons for the students' disdain. First, the possibility of being professionally disciplined was so remote that the complicated rules and the cases interpreting them seemed irrelevant, especially compared to the subject matter of other courses, such as evidence, tax, or antitrust, which they

2. For exhortation by leaders of the bar, see AMERICAN BAR ASS'N, SECTION OF LEGAL EDUCATION AND PROFESSIONAL DEVELOPMENT, AN EDUCATION CONTINUUM: REPORT OF THE TASK FORCE ON LAW SCHOOLS AND THE PROFESSION: NARROWING THE GAP (1992) [hereinafter MACCRATE REPORT]; COMMISSION ON PROFESSIONALISM, AMERICAN BAR ASS'N, “. . . IN THE SPIRIT OF PUBLIC SERVICE": A BLUEPRINT FOR THE REKINDLING OF LAWYER PROFESSIONALISM (1986). For comments doubting the possible efficacy of such exhortation, and raising the question whether the legal profession is capable of self-regulation, see MARY ANN GLENDON, A NATION UNDER LAWYERS: HOW THE CRISIS IN THE LEgAL PROFESSION IS TRANSFORMING AMERICAN SOCIETY (1994); ANTHONY T. KRONMAN, THE LOST LAWYER: FAILING IDEALS OF THE LEGAL PROFESSION (1993); SOL M. LINOWITZ WITH MARTIN MAYER, THE BETRAYED PROFESSION: LAWYERING AT THE END OF THE TWENTIETH CENTURY (1994); Deborah L. Rhode, Why the ABA Bothers? A Functional Perspective on Professional Codes, 59 TEX. L. REV. 689 (1981).

3. See, e.g., Paramount Communications, Inc. v. QVC Network, Inc., 637 A.2d 34, 51 addendum (Del. 1994); Steve Weinberg, Hardball Discovery, 81 A.B.A. J. 66 (1995). 
knew they had better understand if they were to hold their own in the competitive world they were about to enter. Second, the notion that professional responsibility meant more than merely obeying rules of professional conduct seemed preachy. Granted, being a "good lawyer" meant more than merely obeying the rules. But who was the teacher to tell them what being "good" meant? They could, and would, decide that for themselves.

It was not only the students who had problems with the course. So did the faculty, whose attitude tended to mirror that of the students': To the extent that the law of professional responsibility was "hard law," it was not seen as central to the scholarly enterprise; no well-advised junior member of the faculty sought tenure by doing research on professional responsibility. Nor did faculty members like preaching, or to be seen as preaching, especially without much basis in practical experience. It is one thing to do scholarly research in the law of evidence, another for someone who has tried very few cases to say how the "good lawyer" should try a case. A frequent result of this faculty attitude was that the course on professional responsibility was assigned to a junior faculty member who did not have the clout to refuse, or to a practicing lawyer recruited as an adjunct who was unlikely to know the cases and prone to resort to war stories.

While there have been some changes in this situation, and much splendid work has been done, ${ }^{4}$ a great deal remains-not simply to be done but to be

4. The field of professional responsibility has been given the structure and rigor of an academic discipline comparable to that of other fields of law. Notable among the scholars contributing to this development are Professors Hazard, Hodes, and Wolfram. See, e.g., GeOfFrey C. HAZARD, JR., Ethics in the Practice of LaW (1978); Geoffrey C. HaZard, JR. \& W. William Hodes, The LAW OF LAWYERING: A HANDBOOK ON THE MODEl RULES OF PROFESSIONAL CONDUCT (2d ed. 1990 \& Supp. 1996); CHARLES W. WOLFRAM, MODERN LEgAL ETHICS (1986).

Many fine casebooks have been written and kept up to date by successive editions. Those we have taught or borrowed ideas from include the following: STEPHEN GILLERS, REGULATION OF LAWYERS: Problems of Law and ETHics (4th ed. 1995); Geoffrey C. Hazard, JR., ET al., The Law and Ethics of Lawyering (2d ed. 1994); andrew L. Kaufman, Problems in Professional Responsibility (3d ed. 1989); Thomas D. Morgan \& Ronald D. Rotunda, Professional. Responsibility: Problems AND MATERIAls (6th ed. 1995); and DEBORAH L. RHODE \& DAVID LUBAN, LEGAL ETHICS (2d ed. 1995). The subject has been made accessible to the practicing bar by the $A B A / B N A$ Lawyers' Manual on Professional Conduct, as well as by Professor Wolfram's MODERN LEGAL ETHICS, supra, and HAZARD \& HODES, supra. A forum for scholarly articles has been provided by The Georgetown Journal of Legal Ethics as well as by other law reviews. Useful anthologies, collecting and organizing many of the best of these articles around principal themes, are GEOFFREY $C$. HAZARD, JR. \& DEBORAH L. RHODE, THE LEgal ProfESSION: RESPONSIBILITY AND REGUlation (3d ed. 1994) and THOMAS B. METZLOFF, PROFESSIONAL RESPONSIBILITY ANTHOLOGY (1994).

Some scholars have brought new perspectives from other disciplines, notably philosophy. See, e.g., THE GOOD LAWYER: LAWYERS' ROLES AND LAWYERS' ETHICS (David Luban ed. 1983); Ted Schneyer, Moral Philosophy's Standard Misconception of Legal Ethics, 1984 WIS. L. REV. 1529; see also Elizabeth DVORKIN ET AL., Becoming a LaWyer: A Humanistic PERSPECTIVe on legal EDUCATION AND PROFESSIONALISM (1981); HOWARD LESNICK, BEING A LAWYER: INDIVIDUAL Choice and Responsibility in the Practice of LAw (1992); THOMAs L. SHAFFer \& Robert F. COCHRAN, JR., LAWYERS, CLIENTS AND MORAL RESPONSIBILITY (1994).

Academic centers devoted to the study of professional responsibility have been established, among them the Center for Ethics in Public Policy \& the Professions at Emory University, the Harvard University Program in Ethics and the Professions, the Keck Center on Legal Ethics at Stanford University, and the Center on Professionalism at the University of Pennsylvania Law School. 
imagined-before courses on professional responsibility will do what they should do: teach law students how they may become members of a profession that will deserve the respect to which it pretends.

\section{B. An Attempt To Do Better}

In 1987, the Center on Professionalism was established at the University of Pennsylvania Law School. The Center brought together faculty members, practicing lawyers, and members of the judiciary, working with the Center's staff of attorneys to develop and teach professional responsibility courses. Broadly stated, the Center's mission was to develop teaching materials for lawyers and law students in response to the profession's and the public's sense that lawyers' ethics needed considerable repair. A specific and immediate objective was to develop a course on professional responsibility that would pierce student apathy and disdain. The aim was to impart some sense that the practice of law was much more than mastering new and complex fields to serve one's clients: it should be a life-long adventure in self-definition and ethical development.

\section{Five Basic Premises}

It is in undertaking to accomplish the Center's mission that we have engaged in the exploration referred to in the title of this paper. We state here the basic premises we have formulated, not because we think them the only or best premises on which one should proceed, but because for us, they have produced courses that have been a pleasure to teach and, we believe, have mattered to our students.

1. A Course on Professional Responsibility Must Not Be Limited to Teaching Law Students and Lawyers How to Comply with Professional Rules of Conduct in Order to Avoid Discipline. To teach such a course is tempting: law students will learn how to pass the standard multiple choice examination in professional responsibility, lawyers will think the course at least practical, and professors will avoid any preaching. But it will be an intellectually dishonest course and will deserve the disdain it will receive.

There are no rules to which a teacher can point as an authoritative statement of how every lawyer must act to avoid discipline. There used to be such a statement, for almost every jurisdiction adopted the American Bar Association's Model Code of Professional Responsibility shortly after its promulgation in 1969. In 1983, however, the Association promulgated its Model Rules of Professional Conduct and consensus has broken down. ${ }^{5}$ Whether consensus will

5. By 1980 , nearly every state had adopted a code of professional responsibility modeled on the ABA Code, but fewer than fifteen states now retain the Model Code. Most states have adopted some version of the ABA Model Rules of Professional Conduct. STEPHEN GILlERS \& ROY D. SIMON, JR., REGULATION OF LAWYERS: STATUTES AND STANDARDS 423 (1996). 
be restored by the forthcoming American Law Institute's Restatement of the Law Governing Lawyers remains to be seen.

To be sure, in a continuing legal education course, the teacher can point to authoritative rules: the rules of the jurisdiction in which the course is being taught. But that is not possible in a law school, where the students will practice in many jurisdictions. Even in a continuing legal education course, this teaching method is parochial because many lawyers today practice in more than one jurisdiction.

Thus, a teacher who announces to the class, "I'm here to teach you the rules, not to tell you what is right or wrong" must decide how to answer the question "Which rules?" And whatever the answer, it will necessarily, to a degree, be arbitrary.

The answer will also be dogmatic. At least since Sharswood, ${ }^{6}$ lawyers have revised their rules of conduct. The debate leading to such revisions has intensified. Thirty-seven jurisdictions, for example, either permit or require more disclosure of confidential information than is permitted by Model Rule 1.6.' Academics and practicing attorneys continue to disagree on many issues confronting the legal profession, for example: the definition of lawyers' obligations to third parties; whether they may be partners with other professionals, such as accountants; the limits on their right to advertise; whether they must provide pro bono services; and how they should deal with potential conflicts of interest. A course on professional responsibility that conceals or obscures this ferment by presenting a particular formulation of rules of conduct as though it were a complete or satisfactory definition of a lawyer's obligations is an impoverished course.

2. A Course on Professional Responsibility Must Acknowledge That in Deciding What Is the Professionally, Responsible Course of Action, a Lawyer Must Go Beyond the Rules of Conduct and Consider the Demands of Personal Conscience. The rules themselves, in every formulation, make this plain. Consider, for example, the definitions of a lawyer's obligation to keep a client's confidence and to counsel a client. The obligation to keep confidences is not stated as an absolute but as a general obligation, with provision made for exceptional circumstances in which the lawyer "may" disclose a confidence. ${ }^{8}$ Yet, no guidance is provided on whether to exercise this discretion. Nor do the

6. George Sharswood, An Essay on Professional Ethics, in A COMPEND Of LeCtUREs ON THE Aims aNd DUTIES of THE PROFESSION OF THE LAW. DELIVEREd Before THE LAW Class OF THE UNIVERSITY OF PENNSYlVANIA (1854); see also DAVID HofFMAN, Fifty Resolutions In Regard To Professional Deportment, in 2 A CouRse of LEgAL STUDY, ADDRESSED TO STUDENTS AND THE PROFESSION GENERALLY 752 (2d ed. 1836).

7. Fred C. Zacharias, Fact and Fiction in the Restatement of the Law Governing Lawyers: Should the Confidentiality Provisions Restate the Law?, 6 GEO. J. LEGAL ETHICS 903, 913-14 (1993). For a fine collection and comparison of rules of conduct, see GILLERS \& SIMON, supra note 5.

8. See, e.g., Model Rules Of Professional Conduct Rule 1.6 1995); Model Code of PROFESSIONAL RESPONSIBILITY DR 4-101 (1980). 
rules provide a suggestion as to how an attorney should resolve the potentially competing professional and moral demands. To instruct lawyers that they "may" disclose is the same as saying, "Whether to disclose is a question of personal conscience and you may disclose if you think that is the right thing to do."

A similar dilemma is posed by the obligation to counsel a client. A lawyer has an absolute obligation to counsel clients on the law to enable them to understand what the law requires or, if the law is unclear, the risks of possible courses of action. But in addition, under a typical formulation, a lawyer "may" refer to such "moral ... factors" as "may be relevant"-again, with no guidance being provided on whether to do so. Here, the requirement to consider the demands of personal conscience is explicit. Whether a particular "factor" is "moral" and "relevant" is a question that different lawyers will answer differently as their individual consciences dictate.

It is therefore impossible for a teacher of professional responsibility to avoid confronting issues that implicate a lawyer's exercise of personal conscience. Sooner or later a member of the class will ask, "Should or shouldn't I disclose a confidence? Or tell a client that I consider a contemplated action, though legal, immoral?" More fully stated, the questions are the following:

I recognize that the rules return me to my individual conscience. But in acting on my conscience, I will be acting as a lawyer bound to obey my profession's rules. Do the rules mean that in certain situations, I may disclose a confidence, or counsel on moral factors, but that I should be very, very wary about doing so? Or do they go the other way and encourage me to do what I think is right, even when I know my client disagrees?

These are not personal questions outside the rules; they are prompted by the desire to understand the rules. Thus, they cannot and should not be avoided. Nor may a teacher simply reply, "Do as you like."

3. Opinions by Courts and Bar Association Ethics Committees Are Not Satisfactory as the Basic Units of a Course on Professional Responsibility. The difficulty with a written opinion is that the reader knows the end of the story. The lawyers in the case, however, did not. In real life, ethical issues arise in one of two ways. One way is that a lawyer fails to recognize that a problem exists. The other way is that the lawyer recognizes that a problem exists and tries to solve it, which may lead to other problems, and so on, until a result, happy or disastrous, is reached. Written opinions tend to obscure this process. Although an imaginative teacher may bring it to the surface, courts tend to focus on the lawyer's last choice and to decide whether that was a mistake, rather than considering the earlier dilemmas that led to that last choice.

9. Model Rules of Professional CONDUCt Rule 2.1; see also MODEl CODE OF PROFESSIONAL RESPONSIBILITY EC 7-8. 
Written opinions should be assigned reading, for one simply cannot understand, much less criticize, the rules without reading the cases. But it is not in the cases that the rules come alive. It is in the lawyers' offices, when, late at night, they ask, "Now what do we do?"

4. The Basic Unit of a Course on Professional Responsibility Should Be a Dramatic Story about Lawyers Who Must Make Ethical Choices. The validity of this premise depends on the story and how it is told. We craft the story as part of a case study. We determine the issues that we want to consider and then write a story that illustrates those issues. Sometimes the story is based on actual events, sometimes it is fictional, often it is a mixture of both. In our course materials and in the modules to be described below, we dramatize the story in a professionally produced videotape.

We use the videotape as the focus of a class. The students do not know how the story ends because the videotape, which lasts only about twenty minutes, is not played straight through. Instead, the videotape is divided into a series of brief scenes. After each scene, the teacher stops the tape and discusses with the class what they have watched. The class is asked to identify the ethical problems presented by the scene and to discuss the lawyer's response to them. This discussion requires familiarity with the rules of conduct, cases, and other reading assigned as part of the lesson. The next scene reveals further problems to be resolved based on the decisions made previously. At each stage, the lawyer's decisions are at least arguably permitted by the rules of conduct and reflect the individual lawyer's conception of the role a lawyer should play. Gradually, the lawyer becomes increasingly entangled in difficulties, until, by the last scene, the lawyer's situation is desperate, if not irretrievable. This leads to the question "What went wrong?" and prompts re-examination of the entire series of decisions the lawyer made, as well as reflection upon the validity of the lawyer's conception of the role lawyers should play.

For example, in one videotape case study we have developed, two lawyers conduct an in-house investigation for a corporate client to determine the accuracy of the client's reports to a government agency. Gradually, the lawyers come to a bitter parting of the ways regarding the need to file a supplemental report. $^{10}$

We have found that our videotapes ${ }^{11}$ pack a wallop for both law students

10. Representing the Corporate Client: The Saga of Albinex, in University of Pennsylvania Law School Center on Professionalism, ProfessionAl RESPONSIBILITY FOR LAWYERS: A GuIDED COURSE (1990) (hereinafter GuIDED COURSE). This case study and the other four case studies in the Guided Course series were principally written by Janet G. Perry and Eleanor W. Myers, now of Temple University School of Law. See infra note 11.

11. In addition to The Saga of Albinex, supra note 10, the Center on Professionalism has developed the following videotapes: Who's in Charge? The Lawyer as Counselor (1989); Conflicts of Interest in Corporate Transactions: The Buyout of the Harris Chemical Company, in GUIDED COURSE (1989), supra note 10; Professional Responsibility in Pretrial Litigation: The Morgantown Civic Center Collapse, in GUIDED CoURSE (1990), supra note 10; Conflicts and Confidentiality: Trouble at Upper Black Eddy, in GUIDED COURSE (1991), supra note 10 (with the assistance of Nancy Brockway and Joan Saltzman); 
and lawyers in continuing legal education courses. The videotapes are powerful because they depict conflicting conceptions of professional responsibility. In the videotape depicting an in-house investigation, the senior lawyer believes that the client is entitled to an opinion letter stating that it need not file a supplemental report identifying possible adverse reactions to a drug marketed by the client. Literally read, the lawyer argues, government regulations do not require such a report, and the client's chairman of the board does not want to file one because a special committee appointed by the company has reported that there are no such adverse side effects. The chairman fears that the supplemental report may cause the government agency to alert doctors about possible negative reactions and the resulting publicity will depress the value of the company's stock. The junior lawyer believes it would be wrong to write the desired opinion letter; he is afraid that the special committee's conclusions may be wrong, and if so, a great many people may be hurt. While the senior lawyer gives priority to a lawyer's role as an advocate, who, within the limits of the law, should help the client achieve its objective, the junior lawyer gives priority to a lawyer's role as a public citizen. Asked which lawyer's choice of role they prefer, students and lawyers are quickly swept into an intense discussion that demands not only that they know the rules and cases but that they ponder a lawyer's ultimate responsibility.

As a result of teaching our videotapes in our basic, required course on professional responsibility, we no longer use a case book to provide the organizing structure of the course. Instead, the course is built around the themes illustrated by case studies. Readings that the students will need to analyze the issues presented by the videotapes are assigned from our own course materials-a loose-leaf binder of cases, ethics committee opinions, rules of court, and excerpts of law review articles—or from a casebook. The students also use a current set of representative rules of conduct. Integrating the readings with the dramatic story creates an educational setting where students approach ethical issues both experimentally and analytically. ${ }^{12}$

and Counseling and Negotiation: The Settlement of Lancer v. American Steel, in GUIDED COURSE (1991), supra note 10. Professor Michael E. Wolfson of Loyola Law School, Los Angeles, has produced, with the support of the W.M. Keck Foundation, two fine videotapes, STATE VS. ONE LATE MODEL Automobile (A Criminal Case) and The Resort InVestment (A Civil Case) (Loyola law School, Los Angeles 1993); with his permission, the Center has slightly changed them and incorporated them as Representing the Family of a Corporate Client: Matt's Case and Ethical Issues in Corporate Representation: Seaside Resort Investment into the series of tapes it uses for continuing legal education. Others have developed effective videotapes. See, e.g., TIMOTHY P. TERRELL, ETHICS AND Professionalism in the Pretrial Stages of Criminal Prosecution and Defense: The Case OF THE Blue Lagoon Nightclub (Chief Justice's Commission on Professionalism, State Bar of Georgia 1993); STEPHEN GILlERS, ADVENTURES IN LEGAL ETHICS and FURTHER ADVENTURES IN LEGAL ETHICS (N.Y.U. School of Law 1993).

12. The course is divided into parts corresponding to a lawyer's differing professional duties. Thus, Part I concerns a lawyer's obligations as counselor; Part II, a lawyer's duty to keep a client's confidences, this being subdivided into two sections, one on the confidentiality rules, the other on attorney-client privilege and work product; Part III, a lawyer's duty of loyalty; Part IV, a lawyer's duties as advocate; and Part V, a lawyer's duties to others than clients. The concluding section, Part VI, 
5. A Professional Responsibility Course Should Be Agnostic; It Should Not Promote A Particular Philosophy, or Conception, of Professional Responsibility But Should Challenge and Help Law Students to Form Their Own Conception, and Lawyers to Revisit Theirs. Many teachers disagree with this premise. Some have argued that a lawyer's principal role should be as a vigorous advocate ${ }^{13}$ or as a public citizen with duties rooted in theology or moral philosophy, ${ }^{14}$ or as an independent professional responsible for defining the just outcome. ${ }^{15}$ While we have said above that a teacher should not seek to avoid all moral discussion by teaching only the rules, we do not believe that it follows that a teacher should promote any particular conception of the "good lawyer."16

Lawyers must play different roles that sometimes make irreconcilable demands. It may be impossible for a lawyer, as a devoted agent, to keep a client's confidence, and at the same time, as an officer of the court, fulfill the role of a privileged professional with special responsibilities for the quality of the legal system. In theory, perhaps, such an impossibility does not really exist; it may seem to, in a particular case, but, the argument goes, the quality of the legal system must be judged from a general point of view, and from that point of view, confidences should always be kept because more justice than injustice will result. This argument has not carried the day; the rules, in every current version, permit disclosure in some situations. By deciding "I will disclose" or "I will not," a lawyer chooses one concept of professional responsibility over another, and in so doing makes a choice as to his or her proper role.

Most of the principles of professional responsibility are relatively straightforward, and our videotapes are designed to teach them. In the case study mentioned above as depicting an in-house investigation, for example, a lawyer is shown interviewing a corporate employee. If one understands Model Rules

includes materials designed to allow the students to consider the balance they want to achieve between these sometimes conflicting duties.

13. E.g., Monroe H. Freedman, Professional Responsibility of the Criminal Defense Lawyer: The Three Hardest Questions, 64 MICH. L. REv. 1469 (1966); Stephen L. Pepper, The Lawyer's Amoral Ethical Role: A Defense, A Problem, And Some Possibilities, 1986 AM. B. FOUND. RES. J. 613.

14. E.g., THOMAS L. SHAFFer, ON BEING A CHRISTIAN AND A LAWYER: LAW FOR THE INNOCENT (1981)(theology); David Luban, The Lysistratian Prerogative; A Response to Stephen Pepper, 1986 AM. B. FOUND. RES. J. 637 (moral philosophy).

15. E.g., William H. Simon, Ethical Discretion in Lawyering, 101 HARV. L. REV. 1083 (1988).

16. Compare Andrew L. Kaufman, A Commentary on Pepper's "The Lawyer's Amoral Ethical Role," 1986 AM. B. FOUND. RES. J. 651, 655 (arguing that there should be no "prepackaged answer" to the question of what role a lawyer should play and that "[t]here is something to be said for [lawyers] being forced to figure [that] out for [them]selves") with Pepper, supra note 13, and Luban, supra, note 14. See also Eleanor W. Myers, "Simple Truths" About Moral Education, 45 AM. U. L. REV. (forthcoming Spring 1996) (". . . I propose that we openly proclaim the variety and diversity of professional work so our students can seek a practice that fits their personal styles and utilizes their skills. They should not leave law school believing that there is a single conception of being a good lawyer that requires them to suppress their best instincts."). 
1.13 and $4.4^{17}$ and the attorney-client privilege, the lawyer's mistakes are clear. But the hard questions, the questions that can be answered only by calling upon one's conscience to define the lawyer's role, remain.

In our view, a course on professional responsibility should identify but not purport to answer questions of personal conscience. There are no clear answers, and to teach clarity where there is none will not advance understanding. We do not mean that a teacher should not say, if asked, how the teacher would personally resolve a particular ethical problem. But there is a difference between saying, "I would do this, and here's why," and, "This is what you should do."

The teacher's more valuable role is to lead students to recognize the prevailing views of lawyer roles and to encourage debate on the merit and legitimacy of those views. Only from such recognition and debate can worthwhile changes come. It is that process that we hope our teaching materials encourage.

\section{Designing The Basic Law School Course on Professional Responsibility}

In designing our basic course for law students, we follow two methodological principles derived from the basic premises we have just stated. As we shall explain later, we apply these principles in designing other courses as well. We believe they result in more effective, engaging, and challenging courses, not only for law students but also for practicing lawyers and judges.

The first principle we follow is that the composition of a successful dramatic story for use in a professional responsibility course must involve, from the beginning, practicing lawyers. A single faculty member, working alone, may make up a good story, but it may not be good enough. The issues may not be the ones that other lawyers find most troublesome, or if they are, they may be obscured because some of the details of the story differ from situation to situation. But when one convenes a highly qualified advisory committee of lawyers, teachers, and ideally, some non-lawyers, and presents the committee with the preliminary draft of a case study and a script, the result is invariably gratifying. Issues are sharpened, new issues suggested, details adjusted, and the script can be produced on videotape. The basic course should acquaint students with the sort of ethical problems they will encounter as practitioners; the course will not do that unless practitioners are included when it is designed.

Since the story in question will involve a specialized area of law, for example, environmental, family, or product liability law, the committee should include practitioners experienced in that area. Their practice styles must not be all alike; no committee composed of only big-firm, corporate defense lawyers or only plaintiffs' personal injury lawyers will be effective. The videotape will be presented to classes that include all sorts of persons who will define a

17. Model Rule 1.13 is entitled "Organization as Client"; Model Rule 4.4 is entitled "Respect for Rights of Third Persons." MODEl Rules OF PROFESSIONAL CONDUCT Rules 1.13, 4.4. 
lawyer's proper role by reference to very different experiences and standards. An effective case study - a good story-anticipates a diverse response.

Our second principle is that before the case study is put in final form it should be test-taught. Test-teaching, especially when repeated, results in further revision, typically making the story move more swiftly to its denouement, or adjusting the relationship of the issues and their respective importance. Testteaching also enables us to produce a teacher's guide that reflects classroom experience. This is especially important because the teacher's guide should enable a law professor who has not taught professional responsibility before to teach the case study effectively.

\section{III}

\section{Beyond The Basic Course: Teaching Professional Responsibility THROUGHOUT THE CURRICULUM}

While we continue to revise our basic course in professional responsibility, our principal effort for law students has become the development of a series of separate units, which we call "modules," designed to provide law schools with a pedagogical structure that will infuse the entire curriculum with concepts of professional responsibility. ${ }^{18}$

\section{A. The Concept of Modules}

Each module will be a self-contained case study related to a selected law school course. The case study will be a dramatic story produced on videotape, similar in format to the case studies we use in the basic course. The story line and the accompanying teaching materials will combine the presentation of a professional responsibility issue with a substantive law issue ordinarily covered in the course. For example, a case study for a family law course might examine the legal issues regarding custody determinations while at the same time asking what duty, if any, a lawyer representing a parent client has to look after the interests of the non-client children. The modules will be designed to fit the usual law school class period and will be coordinated with recognized casebooks or common syllabus organizational patterns in the substantive fields.

The end-product will be a curriculum package containing written student course materials, a videotaped case study or interactive problem, and a teacher's guide. As with all our projects, the modules will be test-taught several times. Upon completion, the modules can be published and made available as individual units so that law professors may select the appropriate module for their particular course. The comprehensive teacher's guide that will accompany the module case study will provide extensive examination of the issues and source materials. With the guide, a law school teacher unfamiliar with teaching

18. As we mentioned in the beginning, this is one of the two projects that we have undertaken with the support of the W.M. Keck Foundation. 
professional responsibility will be able successfully to integrate ethics into his or her course.

\section{B. Why Supplement a Foundation Course with Modules?}

Why can we not be satisfied with the good basic course in professional responsibility we have described above? After all, it is required of every student. And if we make it lively and comprehensive, students will have a firm grounding in the law of lawyering when they graduate. We think more is required; here's why.

First, in the practice of law ethical issues do not arise in isolation as separate questions presented by a client to a lawyer. They arise in the context of a problem of substantive law that a lawyer is handling for a client. Basic courses are essential to teaching students the law and principles of professional responsibility, but they announce the name of the issue: "Now we will deal with confidentiality (or conflicts of interest, or candor to the court)." In practice ethical issues do not announce their names or even their presence. They slide in surreptitiously while the lawyer is concentrating on drafting a private placement memorandum for a real estate syndication or trying to calm an angry father who wants to punish his former wife by taking the kids away. ${ }^{19}$

It is only fair to our students to allow them to experience the professional responsibility problem as a lawyer experiences it. They need practice in issue recognition and the exercise of judgment about how to apply ethical principles, as well as the law, in situations full of legal and human complexity.

The second reason for creating modules is that a single basic course is insufficient to ground students in the ethical ideals of the profession. The basic course acquaints them with a sampling of analytic tools, but it is a "survey" course that does not allow them the opportunity to use these tools. For example, in the basic course we study the role of the lawyer as counselor. We discuss the lawyer's duty under Model Rule 1.2(a) (Scope of Representation) ${ }^{20}$ to "abide by a client's decision concerning the objectives of the representation" and the lawyer's option to give advice on extra-legal matters under Model Rule 2.1 (Advisor). ${ }^{21}$ We try to make these issues come alive by using one of our videotape case studies ${ }^{22}$ and a variety of hypotheticals. But our discussions

19. See, e.g., FDIC v. O'Melveny \& Myers, 969 F.2d 744, 749 (9th Cir. 1992), rev'd and remanded on other grounds, 114 S. Ct. 2048 (1994), on remand, 61 F.3d 17 (9th Cir. 1995) (private placement memorandum); Garska v. McCoy, 278 S.E.2d 357, 361, 362 (W. Va. 1981) (custody dispute between unmarried parents).

20. MODEl RULES OF PROFESSiOnAl CONDUCT Rule 1.2(a) ("A lawyer shall abide by a client's decisions concerning the objectives of the representation, ... and shall consult with the client as to the means by which they are to be pursued.").

21. Id. Rule 2.1 ("In representing a client, a lawyer shall exercise independent professional judgment and render candid advice. In rendering advice, a lawyer may refer not only to law but to other considerations such as moral, economic, social and political factors, that may be relevant to the client's situation.").

22. Sources we use include Who's in Charge? The Lawyer as Counselor, supra note 11; Counseling and Negotiation: The Settlement of Lancer v. American Steel, supra note 11. 
skim the surface. Unlike a family law course, an ethics course cannot hope to examine the full complexities of representing a young child where different forms of representation exist (attorney for the child, guardian ad litem, attorney for the guardian ad litem) with differing responsibilities, and where determining the "objectives of the representation" is exceedingly difficult. ${ }^{23}$ (Are the objectives the child's expressed interests or the child's "best interests"? If the former, what if those expressed interests are harmful to the child? If the latter, how are best interests determined?)

Third, and finally, the professional responsibility modules will deepen student understanding of the substantive law by forcing them to place themselves into the context of the representation and to struggle with the application of the law. Like law school clinical courses, the modules can create a bridge over the gap between the academic environment of law school and the real-life practice of law. ${ }^{24}$

We therefore strongly believe that both approaches, a basic course and modules for inclusion in the rest of the curriculum, are necessary. Yet there is little material available to help law professors who would like to weave ethical dilemmas into their courses. Few casebooks include professional responsibility issues among their substantive issues, although there are notable exceptions, ${ }^{25}$ and fewer texts are designed to integrate ethics into the broader curriculum. ${ }^{26}$

\section{How We Develop the Modules}

We set about developing our module project following our usual methodology as described above. ${ }^{27}$ We convened an advisory committee composed of law professors from the University of Pennsylvania Law School and from the

23. A great deal has been written on representation of children. Two prominent examples are ANN M. Haralambie, The Child's ATtorney (1993), and Martin Guggenheim, The Right to be Represented But Not Heard: Reflections on Legal Representation for Children, 59 N.Y.U. L. REV. 76 (1984).

24. One of the "Recommendations" of the ABA's Report of the Task Force on Law Schools and the Profession is that "[1]aw schools should play an important role in developing the skill of 'recognizing and resolving ethical dilemmas' and in placing these issues in an organized conceptual framework . . . ." MACCRATE REPORT, supra note 2, Recommendation 16, at 332 . Recommendation 17 states that "Law schools should stress in their teaching that examination of the 'fundamental values of the profession' is as important in preparing for professional practice as acquisition of substantive knowledge." Id. Recommendation 17.

25. Examples of casebooks including professional responsibility issues in the family law area are Judith AREEN, FAMILy LAW: CASES AND MATERIALS (3d ed. 1992); HoMER H. Clark, JR. \& Carol Glowinsky, Domestic Relations: Cases aNd PROBlems (5th ed. 1995); IRA MARK Ellman et al., FAMily Law: CASES, TEXT, Problems (2d ed. 1991); and Robert H. MNOOKIN \& D. Kelly Weisberg, Child Family and State: Problems and Materials on ChILdREN AND THE LAW (3d ed. 1995).

26. The groundbreaking text is DEBORAH L. RHODE, PROFESSIONAL RESPONSIBILITY: ETHICS BY THE PERVASIVE METHOD (1994). Of course, innovative teachers have always created courses that integrate theory, doctrine, and the problems of lawyers in practice. See, for example, the description of Barbara Bennett Woodhouse's course at the University of Pennsylvania Law School called "Child, Parent, and State" in Barbara Bennett Woodhouse, Mad Midwifery: Bringing Theory, Doctrine, and Practice to Life, 91 MICH. L. REV. 1977 (1993).

27. See supra Part II.D. 
other law schools in our region. Those participating included faculty teaching everything from antitrust to torts, tax, professional responsibility, and clinical programs.

We asked our advisory committee to counsel us on the overall educational design of the project, the best methods of implementation, and the selection of substantive law courses for the first modules. The committee advised us that our modules should be designed to teach both the particular substantive law issue and the associated professional responsibility concepts. Professors who would not be willing to give up a portion of their time to add an ethical issue might be more willing to substitute an enhanced way of teaching a substantive issue already included in their curriculum. The advisers also told us to expect resistance from law professors not only because of time pressure, but also because of fears arising from a lack of expertise in the law of professional responsibility and perhaps a lack of experience in practicing law. Many law professors have never, or only briefly, practiced law and therefore do not have a fund of personal experience upon which to draw.

While the possibilities for creating such modules are limited only by the number of courses offered by a law school, we are beginning by developing three modules: one for civil procedure, a traditional first-year course, and two for upperlevel courses-Corporations and Family Law. In selecting these courses, we followed the advice of our advisers to make choices that would assure as much coverage of the student body as possible. We call the first three modules "Representation of the Family," "Representation of the Corporate Client," and "Representation in Litigation." Each of these areas spans a cluster of courses in the law school curriculum. Beginning with one course in each cluster, we recognize that the issues we choose will be pertinent to related courses in the cluster. The related courses may be appropriate choices for a second group of modules. ${ }^{28}$

To develop the three modules selected, a second round of advisory committees is necessary to identify the most significant issues of professional responsibility in the chosen areas of practice. At this stage, we add practicing lawyers and judges to the academic advisers. The practitioners are eager to share the difficult ethical dilemmas that they face in their work. Their stories provide the factual context in which the ethical, legal, or philosophical issues arise.

In the Representation of the Family committee, for example, dozens of issues were raised. Certain issues engendered sharp disagreement among the advisers, particularly the issue of the duty of the divorcing parent's lawyer to look after the interests of the children. Some advisers believed that the parent's

28. For example, the Representation of the Family cluster could include, in addition to family law, trusts and estates, estate planning and administration, and elder law; the Representation of the Corporate Client cluster could include, in addition to corporations, mergers and acquisitions, regulated industries, and securities regulation; the Representation in Litigation cluster could include, in addition to civil procedure, evidence, pretrial civil practice, product liability, and toxic torts. 
lawyer has a duty to the children, perhaps deriving from the parent's own fiduciary duty. Others argued just as strongly that the sole duty is to the parent client. Some believed current standards of professional responsibility resolve the problem; others believed they do not. There was no consensus. ${ }^{29}$ Issues like this, where confusion reigns or tempers flare, are ripe for exploration. We conceive our modules as vehicles for that exploration.

Our aspiration in undertaking this project is to create a comprehensive framework for the study of professional responsibility throughout law school. We would like to see a package that includes a basic course, a set of specialized units with written or videotaped case studies, suggested written student materials (in loose-leaf, so that they could easily be kept up to date), teachers' guides, and videotapes of instructional sessions. A law school that built such an infrastructure of professional responsibility experiences would send its students into the world of practice with a deeper comprehension of the ideals of the profession, an alertness to ethical issues in context, and increased skill in problem resolution.

\section{IV}

\section{Beyond the Law School: Continuing Professional Education}

As mentioned above, the Center on Professionalism was established to develop teaching materials for the law school course on professional responsibility and continuing legal education courses. At first, we regarded these responsibilities as distinct, but we soon learned otherwise. If a videotape is to work as a unit in a course for law students, it must work for lawyers. The course for students should acquaint them with the sort of ethical problems they will encounter as practitioners. A videotape that does that is one to which practitioners will respond; if they do not respond, the videotape should not be used to teach either practitioners or students. Thus, we discovered that as we were developing courses for our students, we were also developing courses to be used in continuing legal education programs for lawyers.

Many lawyers, especially the lawyers on our advisory committees, urged us to continue in this direction. They reported, and our own observation confirmed, that the usual continuing legal education courses in legal ethics were profoundly unsatisfactory. Often the problems presented were too easy (for example, "Don't mingle clients' funds with your own." "Don't counsel false testimony."). Also, the courses almost never challenged the status quo but taught a particular jurisdiction's rules of professional conduct by rote. Such

29. The American Academy of Matrimonial Lawyers ("AAML") has drafted its own voluntary standards of conduct because the organization believes that "[e]xisting ethical codes often do not provide adequate guidance to the matrimonial lawyer." In particular, an AAML survey "indicated that the harm to children in an acrimonious family dispute was seen as the most significant problem for which there is insufficient guidance in existing ethical codes." AMERICAN ACADEMY OF MATRIMONIAL LAWYERS, BOUNDS OF ADVOCACY 3 (1991); see also AMERICAN BAR ASS'N, FAMILY LAW SECTION, STANDARDS OF PRACTICE FOR LAWYER MEDIATORS IN FAMILY DISPUTES (1984). 
courses were boring and insulted one's intellect. They taught little, except perhaps complacency with the status quo. By contrast, the lawyers on our advisory committees were excited and stimulated by our courses.

It is no doubt true that law students have a "fresher" approach to the legal profession because they have not been battered by the blows of practicing law. But it is a profound mistake to assume that those blows reduce lawyers to a state of cynicism or ennui. Rather, we found lawyers welcome a course that is difficult, not simply in the sense of presenting complex legal materials but in requiring them to reexamine long-held but little-questioned assumptions.

In moving beyond the law school classroom into continuing legal education for lawyers, ${ }^{30}$ we have become convinced that continuing professional education for lawyers is also a responsibility of law schools. Our experience has shown us that one teaches students much more effectively by reaching out to the bar. Besides, it has never been the case that the only responsibility of law schools is to their students; in the end, the purpose of teaching and research is to strengthen, inform, and enrich the understanding of the profession.

FURTHER BEYOND THE LAW SCHOOL: A COURSE ON JUdICIAL ETHICS

One of the most surprising and exciting discoveries we have made in our exploration of professional responsibility as a continuum is that it embraces not only law students and lawyers but judges. The intersection of legal and judicial ethics had not been apparent to us, nor, we found, to lawyers. But we now see that a lawyer, by fulfilling the obligations of an officer of the court, helps a judge to fulfill a judge's ethical obligations. As we worked with the lawyers and judges on our advisory committees, we were encouraged to undertake a course on judicial ethics.

The course on judicial ethics is organized in three parts, one for each of a judge's three worlds: the courtroom (where the judge should ensure that the proceedings are fair); chambers (where the judge should reach a decision that respects the law); and outside the courthouse (where the judge should never act in a way that will impair the ability to serve as a judge). As with our other courses, the basic units of instruction are dramatic stories. Other materials, such as the judicial canons and selected cases and articles will be included as tools to analyze the issues the stories present. In developing the course, we have shuttled back and forth between an advisory committee that includes a distinguished assortment of judges, lawyers, law teachers, and non-lawyers, ${ }^{31}$ and test-teaching.

30. Among the courses presented to lawyers by the Center are those based on the videotapes described supra notes 10 and 11.

31. Professor Saul Touster, the co-founder of the Humanities and the Professions Program at Brandeis University has, from the outset, been an especially generous and thoughtful contributor to this project. 


\section{A. A Course Based on Literature and Film}

The principal difference between the course on judicial ethics and our other courses is that, except for one, the stories we intend to include are drawn from literature and films. In the first part of the course (courtroom), we plan to use our videotape concerning a troublesome deposition, ${ }^{32}$ and a scene from the film To Kill A Mockingbird ${ }^{33}$ depicting part of the trial and Atticus Finch's closing address to the jury. In the second part of the course (chambers), we plan to use scenes from four films: a scene in the doctor's office from Rambling Rose $;^{34}$ the court martial scene from Billy Budd ${ }^{35}$ the trial of Shylock's action on Antonio's bond from The Merchant of Venice; ${ }^{36}$ and a scene from a film based on W. Somerset Maugham's story Mr. Know-All. ${ }^{37}$ The course is designed so that it can be taught using the films, the works of literature on which the films are based, or both. We also plan to use several short stories. ${ }^{38}$ In the third part of the course (outside the courthouse), we will present three case studies: Two are fictional, and one is based on the actual circumstances of Supreme Court Justice Abe Fortas's resignation.

There has been much debate about the relationship between law and literature. ${ }^{39}$ We do not propose to enter that debate. We have not selected our materials for the course on judicial ethics on the basis of any particular theory of how law and literature relate to each other, but rather on the basis of our appraisal of judges as potential students, in contrast to law students or lawyers.

For both judges and lawyers, there comes a point at which their respective rules of conduct offer no guidance, when the judge, like the lawyer, must say,

32. Professional Responsibility in Pretrial Litigation: The Morgantown Civic Center Collapse, supra note 11 1962).

33. To Kill A MockingBiRd (Pakula-Mulligan Productions, Inc. \& Brentwood Productions, Inc.

34. RAMBling Rose (Carolco Pictures, Inc. 1991).

35. BILLY BuDd (Anglo-Allied Pictures, Ltd. 1962).

36. The MerChanT OF Venice (Jonathan Miller Production 1973).

37. TRIO (The Rank Organisation 1950).

38. Among the short stories we have considered in the test-teaching process are the following: Hollis Alpert, The Home of a Stranger, THE NEW YORKER, June 10, 1950, at 26; Susan Glaspell, A Jury of Her Peers, in THE BEST SHORT STORIES OF 1917, at 256 (E. O'Brien ed., 1918); AlberT CAMUS, The Guest, in EXILE AND THE KINGDOM 85 (Justin O'Brien trans., 1958); GEORGE ORWELL, Shooting an Elephant, in SHOOTING AN ELEPHANT AND OTHER STORIES 1 (1950); ISAAC BASHEvis SINGER, A Major Din Torah, in IN MY FATHER's COURT 35 (1962); and William Carlos Williams, The Use of Force, in SHORT STORY MASTERPIECES 510 (Robert Penn Warren \& Albert Erskine eds., 1954).

39. The founding scholar of the view that the study of literature should be part of the study of law is James B. White, whose work, The Legal Imagination: Studies in the Nature of Legal THOUGHT AND EXPRESSION (1973), inaugurated the field now generally referred to as law and literature. For criticism of Professor White and of his critics, see generally RICHARD A. POSNER, LAW AND Literature: A Misunderstood RELATION (1988); RICHARD A. POSNER,OVERCOMING LAW 471, 492-97 (1995); Richard Weisberg, POethics ANd Other Strategies of law AND LITERATURE 188-213, 224-50 (1992)(analyzing Posner, commenting on White). In Law and Literature: A Misunderstood Relation, Judge Posner cites widely not only to writings in the field of law and literature but to works of literature illustrating legal themes. 
"I'm on my own. But this is what I think is the right thing to do." As with our other courses for law students and lawyers, the course on judicial ethics is designed to identify such junctures and to elicit searching discussion about them. To elicit searching discussion from law students and lawyers, however, is one thing; from judges, it is another. Judges are used to listening to others as persons in command, free to interrupt, to change the subject, to end the discussion. They do not readily respond to direct challenge, as students and lawyers will, often for the sheer fun of it. Sometimes the reason for this resistance is amour propre-the judicial sin. But the most open-minded, eventempered, and even-handed judge will have-and properly so-a sense of institutional responsibility, that causes many judges to erect a wall of reserve.

Nevertheless, our test-teaching has convinced us that we are on the right track. We approach obliquely the ethical dilemmas that confront judges. The literature and films present characters who must make the same sort of choices that judges make, but in settings perhaps remote in time or place or at least not in a modern courtroom. Then, we have found, the judges become objective observers. They do not feel inhibited by fears of seeming to criticize their colleagues or the institution of which they are so central a part. Some marvelously candid and searching comments ensue.

\section{B. Two Illustrations}

To illustrate how this process works, we shall refer to two of the films we use in the course's second part, which considers a judge's obligation to respect and comply with the law. If one asks judges what this obligation means, the ensuing discussion can be pretty dull; it is not instructive, and it will not make anyone rethink the judicial role. Discussion is not dull after the films we use.

In Billy Budd ${ }^{40}$ the captain of a British man-of-war in the late eighteenth century convinces the members of a summary court martial that a sailor should be condemned to death and hanged. The captain acknowledges that the sailor is innocent in the sense that he did not intend to kill the man he struck but was provoked by a false and malicious accusation. Nevertheless, the captain argues, under the law the sailor must be found guilty. Judges asked to respond to the captain's argument quickly find themselves discussing ancient questions, which are also questions that confront them every day, and which different judges answer very differently: How should judges decide what the law is, in order to respect and comply with it? Is the law as autonomous as the captain asserts? As inflexible? At what point does a judge's attempt to adapt the law to changed circumstances, or to mitigate its rigors, become a failure to respect the law?

The scene from To Kill a Mockingbird ${ }^{41}$ challenges judges to consider when to transcend the prevailing concept of justice. Sometimes judges have been

40. BILLY BUDD, supra note 35.

41. To KILl A MOCKINGBIRD, supra note 33. 
instruments of protecting the weak, but other times they have enforced the dictates of an oppressive society. How do judges recognize the role they are playing? Atticus Finch's role was to be champion for his client. What makes Finch such a sympathetic character is that he tries so hard, while knowing that he has almost no chance of overcoming the racial prejudice the jury bears his client. But what of the judge's role? Did he, too, recognize and try to overcome the community's racial prejudice? What might or should he have done to protect the defendant? Are the courts today sometimes unwitting instruments of injustice? How can such situations be recognized?

These are not easy questions to put to judges, because the questions may be heard as personal challenges. They are, nevertheless, important questions that we think a course in judicial ethics should ask.

\section{VI}

\section{REFLECTIONS}

When we were invited to participate in the conference on legal ethics at Duke University Law School, held in November 1995, we were asked to submit two papers, one on our module project, the other on our judicial ethics project. We decided, however, that we should discuss both projects in a single paper to make clear our view that they were not distinct but rather two of several inseparable parts of a single subject, a continuum, as we thought of it, each part supporting, informing, and enriching the others.

In beginning this paper, we said we were driven by both optimism and despair. The despair derives from the massive inertia of the legal profession in general and of the academy in particular. But despair does not exclude hope, and as we reflect upon the path we have followed and the lessons we think we have learned, we do have hope. Since we think these hopes have a realistic, though difficult, chance of realization, we shall conclude with a statement of what we hope will be, and believe should be, done.

Experimentation in the development of courses in legal ethics, for students and the bench and bar, should continue. The continuum should be further extended to include consideration of the ethical principles of other professions, for example, medicine, engineering, and business. ${ }^{42}$ Other legal systems, too, should be considered. As the economies of the world become increasingly interdependent, it is common for lawyers from different countries with different rules of professional conduct to participate in the same legal transactions. ${ }^{43}$

42. The Center's courses have already been taught in interdisciplinary formats with these professions.

43. Scholars have started to address at least the domestic fragmentation and diversity of professional standards. See, e.g., Stephen B. Burbank, State Ethical Codes and Federal Practice: Emerging Conflicts and Suggestions for Reform, 19 FoRDHAM URB. L.J. 969 (1992); Linda S. Mullenix, Multiforum Federal Practice: Ethics and Erie, 9 GEO. J. LEGAL ETHICs 89 (1995); Fred C. Zacharias, Federalizing Legal Ethics, 73 TEX. L. REV. 335 (1994). In January 1996, the Committee on Rules of Practice and Procedure of the Judicial Conference of the United States convened a special study 
The legal profession asserts its ability, and prerogatives, to regulate itself, but its performance in this regard has been poor. Change, of course, does not come only from within. Economic pressures, for example, have transformed the practice of law and lawyers' views of their professional duties. Courts, too, are reexamining their role. But we should not simply yield to outside pressures; we should try to understand them to determine if what is precious to us can be preserved. We think of our efforts at the Center, and this article, as a very modest effort in that direction.

In our view, if the effort is to succeed, it must be the result of an informal but self-conscious partnership of the bench, bar, and academy. But the academy, we believe, should take the lead, for it has resources of time for reflection and scholarship, and it can bring a searching objectivity to the task, beyond the resources of the bench and bar. And so we end as we began: We are persuaded that if the legal profession is to come closer to achieving its ideals-indeed, even understanding and articulating what its ideals are-the study and teaching of legal ethics must be transformed to embrace every aspect of the law school curriculum and to reach beyond the law school to the bench and bar. By itself, even so great a change will not be enough. But without it, the profession will continue on its present course, preaching its virtue while deserving the contempt its scoundrels bring down upon it.

conference to discuss a report prepared by Professor Daniel R. Coquillette on the fragmentation of local rules governing lawyers' conduct in the federal courts, and to consider whether that conduct should be governed by uniform federal rules. See DANIEL R. COQUILLETTE, JUdICIAL CONFERENCE OF THE UNITED STATES, LOCAL RULES REGULATING ATTORNEY CONDUCT IN THE FEDERAL COURTS (1995); Report Recommends U.S. Rules Regulating Attorney Conduct, 11 LAW. MAN. ON PROF. CONDUCT (ABA/BNA) 199 (1995). 